\title{
Solidarity and Social Justice in Promoting Mental Health and Wellness among Impoverished People: Looking from Mercy and Liberation
}

\author{
Martins AA* \\ Department of Theology, Marquette University, USA
}

*Corresponding author: Alexandre A Martins, Department of Theology, Marquette University, USA, Tel: (414) 288-3165; Email: alexandre.martins@marquette.edu

\section{Review article}

Volume 1 Issue 1

Received Date: August 07, 2018

Published Date: August 23, 2018

DOI: $10.23880 /$ abca-16000101

\section{Abstract}

This paper reflects on issues of justice and mental health from a theological approach that intends to show an ethics of social responsibility and caring ground on a new social Samaritan paradigm. It has the Brazilian context of public health as the starting point for its analysis and an example to support a theological perspective that stresses the crucial importance of a community-based approach able to integrate patient, family, ecclesial community, and society in order to shape public policies that respond to mental health demands and challenges. In addition, this paper suggests an ethics of personal, communal, and social responsibility to avoid marginalization of the mentally ill and enable them to live a healthy sociability according to their limitation and vulnerability. It urges for an ecclesial role in pastoral care for these people and public advocacy for their rights. It shows the Brazilian experience of Pastoral Healthcare in caring for the mentally ill and in advocating for their dignity and rights by its organization in three dimensions: caring - communitarian - sociopolitical.

Keywords: Mental Health; Samaritan Paradigm; Poverty; Community; Liberation

\section{Introduction}

When we talk about health, we have to talk about socio-economic conditions of life and flourishing. Health and diseases are not a phenomenon isolated from life as a whole. So if we want to promote health and healthcare assistance, it is necessary to talk about health inequalities and social justice. Just as health is not a phenomenon isolated from all other human dimensions, mental health is also part of this broad human conjuncture. The World Health Organization affirms: "there is no health without mental health" (no. 2) [1] ${ }^{1}$. It is a simple statement with a huge power of impact because it leads us to a notion of mental health integrated into health and healthcare as only one system. I argue that there is neither mental health nor health without social justice that can address

${ }^{1}$ World Health Organization also says: "Mental Health in a integral part of health and well-being (...) Mental Health, like other aspects of health, can be affected by a range of socioeconomic factors that need to be addressed through comprehensive strategies for promotion, prevention, treatment and recovery in a whole-of-government approach" (WHO, no. 08). 
health inequalities and create better life conditions for those who are vulnerable and marginalized. In this "mathematics," health - mental health-social justice, poverty is the common ground that prevents millions of people from having good health, adequate healthcare assistance, and opportunities for flourishing with dignity according to their values and dreams.

In this paper, I reflect about mental health between these two dimensions: health inequalities and social justice. It is a psychosocial vision of mental health that addresses social determinants of health and mental health and involves the task of integrating the mentally ill into social life, according to their specific needs, limitations, and capabilities. In other words, mental health is part of actions that address health inequalities and promote social justice able to empower people to flourish. In this way, mental healthcare should not be an isolated medical specialty, but a care inside a broad healthcare system and supported by social structures able to integrate the mentally ill into social life.

Considering that poverty is the number one cause of health inequalities and early death in the world, and having in mind that many studies show the connection between mental disorders and poverty (as a factor that makes people vulnerable to get sick physically and mentally, and more vulnerable to social marginalization and early death because of lack of resources to address their health needs), ${ }^{2}$ I will reflect on mental health and social justice from the perspective of those who are carrying the burden of health inequalities, social injustice, and are victims of structural violence [2,3]. It is a liberating perspective from the preferential option for the poor. In Pope Francis' words referencing the CELAM Document of Aparecida, ${ }^{3}$ this option is from the "Christological faith" (Evangelii Gaudium, no. 198) [4,5]. Therefore, I will use theological sources to address ethical concerns regarding mental health and justice.

Grounded on the Catholic theological tradition, especially in ethics and Catholic social teaching, I will address issues of justice and mental health with the preferential option for the poor, as an existential commitment of solidarity, and justice, at its heart. I argue for an ethics of social responsibility and caring, grounded

\footnotetext{
${ }^{2}$ Many scholars demonstrate the connection between mental disorders and poverty (Gonçalves, De Jesus Mariaet al.; Da Gama, Campos, and Ferrer).

${ }^{3}$ This document was issued by the Latin American and Caribbean Bishops after the continental conference that took place in the City of Aparecida, Brazil in May 2007.
}

on a new social Samaritan paradigm. I will do it from a specific context, that is, the Brazilian context of public health, as the starting point to see practices in mental health and an example to support a theological perspective that stresses the importance of a communitybased approach able to integrate the mentally ill, families, ecclesial community, and society in order to shape public policies that respond to mental health demands and challenges.

I suggest an ethics of personal, communal, and social responsibility to avoid marginalization of the mentally ill which enables them to live a healthy sociability according to their limitations and vulnerability. It is a participatory way that can hear and learn from the poor and their experience of caring for those who are sick, even in the midst of their poverty. A community-based approach to health and mental health can promote the participation of families and communities in caring and social integration of the mentally ill. At the same time, this approach, once it is open to listen to the poor, has the potential to empower the poor to be agents of their own lives and to struggle for social justice, a fundamental requirement for mental health. The Christian community can contribute immensely in this process because it has the ability to gather people in a community of solidarity, caring about one another, especially those who are weaker, such as the mentally ill.

Hence, this perspective requires a positive social ministry of the church among the poor, that is, a poor Church that is a Church of the poor, the People of God who live in solidary as a Samaritan community. Based in years of Catholic social ministry in Brazil from below, I urge for an ecclesial role in pastoral care able to care about the mentally ill in their social context of poverty and in public advocacy for their rights. Finally, I will end this paper by presenting the Brazilian experience of Pastoral Healthcare in caring for the mentally ill and in advocating for their dignity and rights by its organization in three dimensions: caring - communitarian - sociopolitical.

\section{The reality of Mental Health and Public Health}

I believe that any study in mental health must come from concrete facts and experiences, especially if the perspective is from the worldview of the poor. Poverty is an undeniable fact that prevents millions of people from flourishing. It is responsible for making people extremely vulnerable to disease and mental disorders. Poverty and illness work in an evil cycle that ends in death: poverty 


\section{Annals of Bioethics \& Clinical Applications}

causes bad health, bad health makes the poor poorer, and the result is early death. It is a social sin that has been perpetuated in history through social mechanisms of violence against those who are disadvantaged. In the early 1970s, liberation theology diagnosed this violence as an institutionalized socioeconomic mechanism that keeps wealth in the hands of the few and prevents the poor from accessing goods they need to flourish [6,7]. The consequences for health and mental health are obvious. Based on liberation theology insights, the medical anthropologist, Paul Famer calls this mechanism structural violence and urges a preferential option for the poor in health (145-52).

The preferential option for the poor in health is a motto that leads us to look at those realities in which people at birth are already condemned to suffer and to die prematurely. In addition, it invites us to join the poor and hear their voices. It is impossible to understand a person's suffering if we are far from him/her; if we cannot look at his/her face and feel the burden of his/her suffering. Regarding mental disorders, the challenge of being with the mentally ill in their poverty is larger. It requires a huge effort of humility, solidarity, and courage like the Good Samaritan. In the company of the poor, solidarity becomes a social virtue with liberating power of social transformation. Far from the poor, all we say about solidarity, caring, and justice are mere concepts. The poor and the sick are tired of hearing about it. The poor do not talk about solidarity. They live it because it is the only way they can survive under structural violence.

Brazil is a country marked by inequalities. Despite all the economic growth in last decades, social disparities and injustices prevent this country of 200 million people from being a place of human flourishing. In healthcare, Brazil can be proud of having a public health system with universal coverage, but structural violence still has an impact on this system and on the lives of those who are poor. The Brazilian public health system, known as SUS (Portuguese acronym for Unified System of Health), was an achievement of the Brazilian people gathered in grassroots social movements led by the health reform movement. Universal coverage is a positive constitutional right that should be provided by the government. SUS is grounded on the principles of universality, integrality, and equity. It is a national integrated system with decentralized management and deliberative popular participation through local, state, and national health councils. It focuses on primary care and health education from community-based actions [8] ${ }^{4}$. It is a system that serves the entire population of Brazil directly and indirectly, but approximately $80 \%$ are SUS dependents [9].

Many issues prevent SUS from improvement. All of them are connected to structural violence. For example, governmental political decisions favor private insurances and hospitals, and cut funding from public health to distribute this money in areas that have a potential for economic growth. However, it is a fragile economic growth because it promotes inequality keeping the poor in their poverty without adequate healthcare and quality education. In short, other problems in SUS are management and lack of resources, such as health professionals, structures, and medical supplies.

I highlight one issue in public health in Brazil: mentality. This allows me to move from the general to the specific of mental health. SUS is organized to solve most health demands in primary care through communitybased centers and healthcare teams who interact directly with families in their homes and communities. It is the Family Health Program. The system begins from the simple to the complex in order to promote population health and to decrease the need of inpatient and high medical specialties. It is a community-based model rather than hospital centered. Here also begins one of the big challenges for SUS because the culture is still oriented by the hospital-centered model of curative character. Despite the fact that the community-based approach is accepted, the insurance company lobby, that is hospital-centered and emphasizes high-tech specialized medicine, creates an atmosphere of competition between public and private healthcare. In mental healthcare, this conflict prevents the public system from consolidating and improving the community-based system that cares for the mentally ill in their interconnection with society.

The movement from the hospital-centered model of mental healthcare - that led the public system to build many psychiatric hospitals to isolate patients from society - to the community-based services with a holistic and interdisciplinary vision is relatively new. The idea of this shift started in the early 1970s, but only in 1990s, after the establishment of SUS, something concrete happened. It was a movement of deinstitutionalization of mental healthcare. It created Centers of Psychosocial Attention

\footnotetext{
${ }^{4}$ To know more about the Brazilian Unified System of Health, see: Sonia Fleury, (2011) "Brazil's health-care reform: social movements and civil society." The Lancelet 377, 9927: 1724-25. Associação Paulista de Medicina (2010) SUS: O Que Você Precisa Saber Sobre o Sistema Único de Saúde. São Paulo: Atheneu.
} 


\section{Annals of Bioethics \& Clinical Applications}

(CAPs) to address mental disorders in a holistic vision in which society, especially families and local communities, participate in the caring process of the mentally ill. The emphasis shifted from a narrow focus on mental disorder to see the mentally ill in their social context. The goal became empowering the mentally ill so that they can be integrated into their families and the broad society rather than being taken away from society to protect it from the mentally ill and vice-versa $[10,11]$.

Mental healthcare is part of SUS and involves families and communities in the process of caring for the mentally ill. It is an integrated system that begins from the bottom. The person with a mental disorder is seen not an object, but as a subject with autonomy. He/she has different levels of limits according to the disorder, but is one who still can be in society. There are outpatient mental health services, but also inpatient mental health units in general hospitals. So the psychiatric treatment is part of healthcare as a whole and not something totally isolated. In addition, this system addresses the context around the mentally ill, especially families and communities, in order to promote education that can empower these groups to deal with those who have mental disorders. It pays attention also to the social context to see the vulnerability of the mentally ill and conditions of risk that can create mental disorders. Hence, the social integration of those who are ill is possible as well as positive preventive actions. Centers of Psychosocial Attention work hand in hand with Family Health Programs and are spread throughout the country [12].

This system is not working as planned. It finds many barriers for its full implementation. First of all, it suffers the same difficulties of the entire public health system [9]. In addition, there remains the social stigma about the mentally ill, the lack of adequate education of health professionals to work in this new way, and the vulnerability of the social context of persons with mental disorders and their families $[13,14]$. I highlight that lack of resources and, above all, poverty are the main causes responsible for the insufficiency of the community-based model in mental healthcare and the social integration of the mentally ill. From the perspective of the poor and the families of the mentally ill, there are no social conditions and structures that allow them to care properly for those who are sick and to integrate them into a social life. For instance, Centers of Psychosocial Attention can give a good outpatient treatment, and provide all necessary medication, but when the person with a mental disorder goes back home, he/she does not have enough food to eat, does not have a bed to sleep in, and cannot find any opportunities to study and/or work. He/she will not find an environment to continue the progress. In addition, the family will not be in a condition to help much because it is living in the same context of scarcity and poverty. This contributes to cause the mentally ill to deteriorate, to be restricted in asylums (that still exist in Brazil), or to live on the streets, and to suffer an early death.

\section{The Samaritan Paradigm and the Preferential Option for the Poor}

In 1983, Gustavo Gutiérrez wrote a book about the poor's experience of faith in Latin America. In this book, We Drink from Our Own Wells: The Spiritual Journey of a People, Gutiérrez develops the idea of the eruption of the poor in history, a phenomenon in Latin America grounded in a liberating spirituality. This irruption was visible in the historical praxis of Christian Communities [7,15]. He says: "The concrete and efficacious commitment of so many Christians to the poorest and most disinherited, as well as the serious difficulties they encounter in their commitment to solidarity, are leaving a profound mark on the history of Latin America ... Solidarity, prayer, and martyrdom add up to a time of salvation and judgment, a time of grace and stern demand - a time, above all, of hope" (24-25).

Solidarity was the way the poor found to survive in the midst of suffering. It begins with an experience of God's love that is among the poor in their suffering. This leads to a communal experience of solidarity among the poor in which, even in their precarious lives, they support one another. Therefore, solidarity is an experience of compassion in which one shares his/her life with another in suffering. In solidarity, one suffers with those who are suffering because of structural violence and its consequences, such as poverty and mental disorders. In this way, we are invited to learn from their faith concretized in an experience of solidarity. The eruption of the poor in history is from their experience of faith, the incarnated God in history, and their practice of solidarity, a practice with sociopolitical impact. Therefore, solidarity is not only a mere feeling, but it is a concrete praxis of liberation toward justice. It is in this way that the poor have cared about those who are mentally ill in a precarious life.

The Good Samaritan parable (Lk 10: 25-37) presents mercy as a deep feeling that leads to a practice of solidarity. This practice touches concretely the life of the one who is in need, and changes it. The action of the Good Samaritan is a practice of solidarity that connects mercy, 


\section{Annals of Bioethics \& Clinical Applications}

as a deep feeling of compassion, and justice, as giving to the other what belongs to him, in this case: healthcare. All of that was possible, because the Good Samaritan looked at the wounded man and contemplated his face. The Samaritan was touched by the suffering of the other. This touching awakened the mercy that makes the Samaritan's heart to beat faster (the Latin word for mercy is misericordia: something from the heart), and he couldn't do anything else, but help [16].

Contemplation of the suffering people's face is crucial to promote dignity and struggle for justice. Our contemporary society talks a lot about poverty, marginalized people, lack of opportunities, and health inequalities. Everybody, who is talking about this reality of poverty and suffering with millions of early deaths, has suggestions to address these issues. Many develop beautiful theories and systems to end poverty. However, those who are actually suffering are not mere numbers, statistics, nor a distant people whom we do not know. In healthcare, the sick and the poor are totally anonymous, without face nor voice. And they are dying every day. Many people create solutions for them, but don't know who they are. These possible solutions are very arbitrary, non-democratic, and elitist because they come from people who are not victims of structural violence nor do they share life with the victims or listen to them. Listening to the poor, engaging them in dialogue, and promoting their participation, these are essential to promote justice and address health inequalities properly.

The Good Samaritan paradigm is a power that leads us to join those who are suffering and to contemplate their faces. Following this path, the preferential option for the poor guides us to be with those who are the least of society, where most mentally ill find themselves with no healthcare. The preferential option for the poor is an invitation to share life with the poor and, as the Good Samaritan, to look into their eyes, to hear their voices, and to contemplate in their suffering faces the suffering face of Christ. Hence, moved by mercy and solidarity, "the preferential option for the poor drives us, as disciples and missionaries of Jesus, to seek for new and creative ways to respond to the effect of poverty" (409). The Good Samaritan paradigm and the preferential option for the poor challenge us to seek for these new and creative ways to address the effects of poverty in mental health.

The Catholic Church, understood as the People of God, must take positive action in healthcare in order to be an advocate (the go'el) for the poor and to promote justice in healthcare. This advocacy is not only the institutional church, but the entire Church of the poor animated by the Holy Spirit who shapes a community of solidarity. It discerns the signs of the time to be creative in its action for justice. The poor are the Church and all are invited to learn from them, to dialogue with them, and to empower them to be agents of social transformation. Learning from the poor does not mean we have nothing to teach them. We have, but this teaching must be dialogical to show we are one community grounded in our faith in Jesus and walking in the same path for justice. Thus Catholic tradition, especially social teaching, has much to contribute to empower the poor and to promote justice in health, if it is used in this dialogical way.

Catholic social teaching (CST) places the human being at the center of socioeconomic action in order to promote an integral human development [17]. Human dignity is an intrinsic value, regardless of mental and physical abilities. It guarantees that all must be able to participate in the common good to provide necessary goods for flourishing. CST, in John XXIII's encyclical Pacemin Terris, stresses healthcare as a positive human right, a good that all should have access in order to live with dignity (no. 11) [18]. People have different needs in healthcare. The mentally ill are an example of those who have specific needs. They have health needs, limitations, and sufferings proper to the condition of having mental disorders. In the context of poverty, these specific needs become more problematic and challenging. Solidarity, as John Paul II stated as a social virtue (Sollicitudo Reis Socialis, no. 38), guides the Christian community to respond to this challenge in a way that the mentally ill will be integrated into social life and supported by family, community, and healthcare providers [19].

The community-based approach to mental healthcare of the Brazilian healthcare system can be developed and improved if the Christian community engages in positive action of caring for the mentally ill and struggling for justice in health. All I have presented here provides foundations from our Catholic tradition to encourage and to support a positive social ministry in mental health and healthcare as a whole.

\section{Ecclesial Action in Justice in Mental Health: Pastoral Healthcare in Brazil}

Now I will present the Brazilian Catholic Community's positive activism in healthcare through the Pastoral da Saúde (Pastoral Healthcare) [20]. The Catholic Church has a long history of social ministry in Brazil. After Vatican II, inspirited by the fresh air from the council, the Brazilian 
Catholic Church began a dynamic activism for justice among the poor. The Conference of Latin American Bishops of Medellín (1968) and Puebla (1979) provided clear directions for the Church's mission in Latin America, a mission grounded in the Gospel and motive by the preferential option for the poor. The Document of Medellín affirms: The Church in Latin America, because the condition of poverty and underdevelopment of the continent, feels it is urgent to translate this spirit of poverty into gestures, attitudes, and norms that make the Church a lucid and authentic sign of the Lord. The poverty of many brothers cries out for justice, solidarity, witness, commitment, effort, and liberation to fulfill the salvific mission entrusted by Christ (no. 7) [21].

It was a clear option for a Church among the poor and their struggle for justice. The Basic Ecclesial Communities were popular expressions of this Church of the poor as a new way of being church. And the Conference of Puebla confirms this expression and its heart, the preferential option for the poor.

The Conference of Puebla reiterates, with a renewed hope in the vivifying strength of the Spirit, the statement of the II General Conference that made a clear and prophetic preferential option for the poor in solidarity, nevertheless mistakes and interpretations that some made and misrepresent the Medellín spirit, ignorance and hostility of the others. We affirm the need for conversion of the entire Church into a preferential option for the poor in order to promote an integral liberation (no. 1134).

In Brazil, this expression of being Church of the poor was also embodied by the social ministry, known as Pastoral Social. Many social ministries raised in the Catholic Church to address social concerns, such as working conditions, urbanism, agrarian reformation, housing, education, infant mortality, gender inequalities, immigration, unemployment, political reform, and healthcare. In the mid 1970s, the Pastoral Healthcare began as a development of the Pastoral of the Sick (or Pastoral Care). The Pastoral of the Sick was a ministry to be in solidarity with the sick and to provide the sacraments. The shift to Pastoral Healthcare began at the time of the Brazilian movement for re-democratization along with the movement for health reform. So the Pastoral healthcare and the Catholic Church became voices for public healthcare and universal coverage. As a result, the Unified Health System (SUS) was created.

Since then, the Pastoral Healthcare has developed and now it is organized in three dimensions that have more than 100 thousand people working as volunteers. With these three dimensions, Pastoral Healthcare aims to serve the poor and sick in their spiritual, physical, mental, and social needs. In order to respond to these challenges, three dimensions -caring, communitarian, and sociopolitical - were created as areas of actions toward promoting dignity and justice in healthcare.

The Caring dimension aims to show the solidarity of the ecclesial community with those who are ill by providing spiritual, emotional, and humanitarian support. The Caring dimension has as its goal being a Samaritan presence (Lk 10, 25-37) for those who are suffering in their homes, communities, and healthcare institutions in order to promote comfort and dignity. Those who work in this dimension also advocate for patients' rights.

The Communitarian dimension focuses on actions from a communitarian setting to promote health education and to be a bridge between healthcare centers and families. The goal is promoting health by education and encouraging people to engage in public health activism. This dimension addresses the social determinants of health, and emphasizes the need of primary care and prevention. It is an activism from the local community to the larger society. The communities, such as Basic Ecclesial Communities, parishes, and communal centers, become centers of popular education for health in two ways. First, communities provide primary care assistance by volunteer health workers. Second, these centers are spaces of popular education for people acting in health councils of the public health system.

The Sociopolitical Dimension focuses on public health. It advocates for justice in health through the role of Pastoral Healthcare agents in the political arena, especially in health councils and conferences. It advocates for public policies with a fair allocation of resources that can prioritize the health needs of the poor. It also acts in monitoring the implementation of public policies through social control and ensures bioethics reflection [20].

The Latin American Bishops adopted this model of Pastoral Healthcare and issued a document that states the objective of this social ministry: "Evangelizing with a renewed missionary spirit the world of health, grounded in the preferential option for the poor and the sick, and participating in the construction of a society that serves life with justice and solidarity" [22].

In mental healthcare, Pastoral Healthcare agents have worked hand in hand with the community-based centers 


\section{Annals of Bioethics \& Clinical Applications}

for mental health. Despite many difficulties and barriers, they have served as a connection between the mentally ill and society. Theirs is a work of supporting families and integrating the mentally ill in their local communities in order to facilitate the process of social integration and the empowerment of the mentally ill. This work is small, but it has produced much fruit in places where the Pastoral healthcare exists. It is a beautiful mission in which the community lives with solidarity as a social virtue. Ecclesially speaking, it is a ministry that originated from below, that is, from the experience of the poor gathered in small communities and was recognized and supported by the bishops.

\section{Conclusion}

This paper followed a method that has become the main theological and pastoral method in Latin America: see - judge - act [23]. In the first part, I presented the reality of mental health in Brazil. In the second, I developed a theological reflection from this the reality. And finally, I introduced the experience of Pastoral Healthcare in Brazil and its activism in mental health as a concrete ecclesial ministry for social justice. The Samaritan paradigm and the preferential option for the poor are at the heart of this paper in which I argue that social justice is necessary to promote mental health because poverty is the main cause of health inequalities, injustices, and early death. Only among the poor, struggling against structural violence, can we promote mental health and justice in healthcare. Paraphrasing the WHO statement, there is no health without mental health and social justice. There is only social justice if the poor can be contemplated and listened to in the dialogical process of liberation.

\section{References}

1. WHO (2013) Mental Health Action Plan 2013-2020. World Health Organization.

2. Gonçalves Daniel A, De Jesus Maria Jair, Peter Bower, Linda Gask, Christopher Dowrick, et al. (2014) Brazilian Multicenter Study of Common Mental Disorders in Primary Care: Rate and Related Social and Demographic Factors. Cadernos de Saúde Pública 30(3): 623-632.

3. Farmer Paul (2003) Pathologies of Power: Health, Human Rights, and the New War on the Poor. University of California Press, Berkeley.

4. Francis Pope (2013) Apostolic Exhortation.

Martins AA. Solidarity and Social Justice in Promoting Mental Health and Wellness among Impoverished People: Looking from Mercy and Liberation. Ann Bioethics Clin App 2018, 1(1): 000101.
5. Conferência Episcopal Latino Americana e Caribe (2007) Documento de Aparecida. Paulus, Edições CNBB, São Paulo.

6. Conferência Episcopal Latino Americana e Caribe (2005) Documentos do Celam. In: Rio de Janeiro, Medellín, Puebla e Santo Domingo, (Eds.), Paulus, São Paulo.

7. Gutíerrez Gustavo (1983) Teologia da Libertação. $4^{\text {th }}$ (Edn.), Vozes, Petrópolis.

8. Fleury Sonia (2011) Brazil's health-care reform: social movements and civil society. The Lancelet 377(9927): 1724-1725.

9. Conferência Nacional dos Bispos do Brasil (2011) Campanha da Fraternidade 2012. Fraternidade e Saúde Pública, Brasília.

10. Borges Camila F, Baptista Tatiana (2008) O Modelo Assistencialem Saúde Mental no Brasil: A Trajetória da ConstruçãoPolítica de 1990 a 2004. Cadernos de SaúdePública 24(2): 456-468.

11. Koda Mirna Y, Fernandes Maria Inês A (2007) A Reforma Psiquiátrica e a Constituição de Práticas Substitutivasem Saúde Mental: Uma Leitura Institutional Sobre a Experiência de um Núcleo de Atenção Psicossocial. Cadernos de SaúdePública 23(6): 1455-1461.

12. Lucchese Roselma, Oliveira Alime GB (2009) Saúde Mental no Programa Saúde da Família: Caminhos e Impasses de uma Trajetória Necessária. Cadernos de Saúde Pública 25(9): 2033-2042.

13. Denise Rebouças, Lúcia Abelha, Letícia Fortes Legay, Giovanni Marcos Lovisi (2008) O TrabalhoemSaúde Mental: Um Estudo de Satisfação e Impacto. Cadernos de Saúde Pública 24(3): 624-632.

14. Pinto Leandro B, Hernández Antonio MB, Kantorski Luciane P (2010) Reforma Psiquiátrica, Trabalhadores de Saúde Mental e a 'Parceria' da Família: O Discurso do Distanciamento. Interface Comunicação Saúde Educação 14(32): 103-113.

15. Gutierrez Gustavo (1984) We Drink from Our Own Wells: The Spiritual Journey of a People. Orbis, Maryknoll, NY.

16. Sobrino Jon (1994) O Princípio Misericórdia: Descer da cruz os povos crucificados. Vozes, Petrópolis. 


\section{Annals of Bioethics \& Clinical Applications}

17. Paul VI Pope (2010) Encyclical Letter Populorum Progressio. In: O'Brien DJ, Shannon TA, (Eds.), In Catholic Social Thought: The Documentary Heritage. Orbis, Maryknoll, pp: 251-277.

18. John XXIII Pope (2010) Encyclical Letter Pacem in Terris. In: O'Brien DJ, Shannon TA, (Eds.), In Catholic Social Thought: The Documentary Heritage. Orbis, Maryknoll, NY, pp. 134-170.

19. John Paul II, Pope (2010) Encyclical Letter Sollocitudo Rei Socialis. In: O’Brien DJ, Shannon TA, (Eds.), In Catholic Social Thought: The Documentary Heritage. Orbis, Maryknoll, NY, pp. 426-438.

20. Coordenação Nacional da Pastoral da Saúde (2010) A Pastoral da Saúde e o Controle Social no SUS no Brasil. Pastoral da Saúde Nacional Press, Uberlândia.
21. Da Gama Carlos AP, Campos Rosan TO, Ferrer Ana L (2014) Saúde Mental e Vulnerabilidade Social: a Direção do Tratamento. Revista Latino americana de Psicopatologia Fundamental 17(1): 69-84.

22. Conferência Episcopal da America Latina e Caribe (2010) Discípulos Missionários no Mundo da Saúde. Guia para a Pastoral da Saúdena América Latina e no Caribe. Centro Universitário São Camilo Press, São Paulo.

23. Boff, Leonardo, Boff, Clodovis (2001) Como Fazer Teologia da Libertação. $8^{\text {th }}$ (Edn.), Vozes, Petrópolis. 